\title{
MENINGKATKAN HASIL BELAJAR CHEST PASS BOLA BASKET MELALUI MODEL PEMBELAJARAN STUDENT TEAMS-ACHIEVEMENT DIVISIONS PADA SISWA KELAS VI SD NEGERI 163084
}

\author{
Erlina Purba \\ Surel : purba.erlina003@gmail.com
}

\begin{abstract}
ABSTRAK
Permasalahan dalam PTK ini adalah Apakah model pembelajaran cooperatif Tipe STAD (Student Teams-Achievement Divisions) dapat meningkatkan hasil belajar Chest Pass Bola Basket di Sekolah Dasar Negeri 163084 Kota Tebing Tinggi? Penelitian Tindakan kelas ini dilakukan di SD Negeri 163084 Tahun Pelajaran 2016/2017 pada bulan Agustus-November 2016. Objek yang diteliti adalah siswa kelas kelas VI SD Negeri 163084 Kota Tebing Tinggi yang besifat heterogen yang berjumlah 36 siswa. Dari hasil siklus I menunjukkan bahwa terjadi peningkatan jika dibandingkan dengan sebelum pembelajaran dengan model pembelajaran kooperatif tipe STAD dari 36 siswa yang mengalami ketuntasan belajar sebanyak 20 siswa (55\%) dan siswa yang tidak mengalami ketuntasan belajar sebanyak 16 siswa (45\%). Pada siklus II siswa yang mengalami ketuntasan belaajar sebanyak 28 siswa (77\%) dan siswa yang tidak mengalami ketuntasan belajar sebanyak 8 siswa (23\%) . Dari perolehan siklus II hasil Belajar siswa sudah mencapai ketuntasan klasikal $75 \%$.
\end{abstract}

Kata Kunci: Belajar, Hasil Belajar, Metode STAD

\section{PENDAHULUAN}

Pendidikan jasmani merupakan bagian dari pendidikan secara umum, yang mengutamakan aktivitas gerak sebagai media dalam pembelajaran. Pendidikan jasmani mempunyai peran yang penting untuk meningkatkan kualitas manusia. Pendidikan jasmani pada dasarnya merupakan bagian integral dari sistem pendidikan secara keseluruhan. Oleh karena itu, pelaksanaan pendidikan jasmani harus diarahkan pada pencapaian tujuan tersebut. Tujuan pendidikan jasmani bukan hanya mengembangkan ranah jasmani, tetapi juga mengembangkan aspek kesehatan, kebugaran jasmani, keterampilan berfikir kritis, stabilitas emosional, keterampilan sosial, penalaran dan tindakan moral melalui kegiatan aktivitas jasmani dan olah raga.

Berdasarkan data yang diperoleh dari seluruh siswa yang ikut dalam proses pembelajaran mengoper dan menangkap bola dapat diketahui siswa-siswi menunjukan angka 39,53\% dari jumlah siswa yang berpatisipasi dalam kegiatan pembelajaran bola basket. Dengan menunjukan angka 39,53\% Siswa yang berpatisipasi dalam kegiatan pembelajaran menjadi bukti kongkrit bahwa pembelajaran bola basket belum sepenuhnya siswa ikut berpatisipasi. Dalam hasil pra penelitian tersebut menunjukan proses pembelajaran belum 

sepenuhnya melibatkan siswa secara aktif, Guru masih menjadi pusat pembelajaran, gaya mengajar serta modifikasi dalam bentuk permainan masih kurang untuk mencapai tujuan pembelajaran.

Dalam permasalahan yang dihadapi guru pendidikan jasmani dalam pembelajaran chest pass bola basket, maka peneliti merasa tertarik untuk melakukan penelitian tindakan kelas (PTK) pada siswa kelas VI SD Negeri 163084 dengan judul "Meningkatkan Hasil Belajar Chest Pass Bola Basket Melalui Model Pembelajaran Student TeamsAchievement Divisions Pada Siswa Kelas VI SD Negeri 163084 Tahun Pelajaran 2016/2017”. Permasalahan ini peneliti temukan ketika observasi di SD Negeri 163084 yaitu dalam pembelajaran gerak dasar mengoper dan menerima bola dalam gerak dasar bola basket.

Berdasarkan latar belakang masalah di atas, maka masalah pada penelitian tindakan kelas ini dapat diidentifikasikan sebagai berikut :

a. Hasil belajar Pendidika Jasmani di Sekolah Dasar Negeri 163084 Tebing Tinggi Tahun Pelajaran 2016/ 2017 masih rendah

b. Dalam mengerjakan tugas-tugas dari guru, banyak siswa yang praktek hanya dengan prakteknya sendiri artinya tidak sesuai dengan rencana pembelajaran.

c. siswa-siswi kurang aktif dan berpatisipasi

d. Siswa merasa jenuh karena tidak ada suatu hal yang dapat membangkitkan gairah untuk bermain.

Adapun rumusan masalahnya adalah : Apakah model pembelajaran cooperatif Tipe STAD (Student Teams-Achievement Divisions) dapat meningkatkan hasil belajar Chest Pass Bola Basket di Sekolah Dasar Negeri 163084 Kota Tebing Tinggi?

Tujuan penelitian yang ingin dicapai adalah sebagai berikut :

a. Memperbaiki peningkatan hasil belajar pada mata Pendidikan Jasmani dengan mengubah strategi pembelajaran yaitu dengan menggunakan model pembelajaran cooperatif Student Teams-Achievement Divisions (STAD)

b. Mencari informasi keaktifan siswa dalam pembelajaran Pendidikan Jasmani tentang Chest Pass Bola Basket dengan menggunakan model pembelajaran Cooperative Tipe Student Teams-Achievement Divisions (STAD)

c. Siswa dapat menguasai materi pelajaran Pendidikan Jasmani dengan menggunakan model pembelajaran Cooperative Tipe Student Teams-Achievement Divisions (STAD)

\section{METODE PENELITIAN}

Penelitian tindakan kelas ini dilaksanakan di SD Negeri 163084 Jalan Tuanku Imam Bonjol Kelurahan Tebing Tinggi Lama 
Kecamatan Tebing Tinggi, lebih tepatnya lagi di kelas VI.

Sebagai subyek penelitian yaitu siswa kelas VI SD Negeri 163084 Kota Tebing Tinggi yang besifat heterogen yang berjumlah 36 siswa.

Waktu pelaksanaan penelitian ini adalah pada semester satu tahun pelajaran 2016 / 2017, tepatnya pada bulan Agustus sampai dengan Oktober 2016. Analisis data penelitian dilakukan dengan tehnik analisis deskriptif. Instrumen Penelitian ini adalah Test Hasil Belajar siswa yang dilaksanakan setiap akhir siklus, hal ini dimaksudkan untuk mengukur hasil yang diperoleh siswa setelah pemberian tindakan. Test tersebut berbentuk multiple choise yang setiap tesnya berjumlah 20 butir soal, dimana setiap jawaban yang benar bernilai 1(satu), jawaban yang salah, mempunyai jawaban lebih dari satu ataupun tidak diisi bernilai 0 (nol) agar banyak materi tercakup.

\section{HASIL PENELITIAN DAN PEMBAHASAN}

Pada saat sebelum pembelajaran model kooperatipf tipe STAD diterapkan, Pembelajaran bersifat satu arah, Yang aktif dalam proses belajar-mengajar didominasi oleh guru. Guru langsung memberikan konsep-kosep pembelajaran tanpa dilibatkannya siswa untuk menemukan konsepkonsep pembelajaran, siswa kebanyakan diam, bahkan ada siswa yang bercerita dengan teman sebangkunya dan tidak adanya umpan balik refleksi saat pembelajaran.

Dalam kondisi seperti ini dari 36 siswa VI hanya 9 siswa atau $25 \%$ yang tuntas dalam belajar. Dalam penelitian ini ada dua aspek yang ingin diukur yaitu Penilaian Proses Pembelajaran dan Hasil Pembelajaran. Tujuan penilaian adalah untuk mengetahui apakah siswa telah atau belum menguasai suatu kompetensi dasar tertentu. Untuk Penilaian Proses Pembelajaran menggunakan teknik Tes. Sedangkan untuk menilai hasil pembelajaran menggunakan soal pilihan Essay sebanyak 10 soal.

Siklus 1 dilaksanakan satu kali pertemuan yaitu Agustus 2016. Materi Pembelajaran yang menjadi bahan penelitian ini adalah Kompetensi Dasar Mempraktikan gerak dasar salah satu permainan bola besar dengan koordinasi dan control yang baik dengan peraturan yang dimodifikasi, serta nilai kerjasama, sportifitas, dan kejujuran.

Untuk mencapai efektivitas pembelajaran telah dibuat Rencana Pelaksanaan Pembelajaran yang disesuaikan dengan model pembelajaran yang akan diterapkan yaitu Kooperatif Tipe STAD. Pada tahap ini peneliti juga mempersiapkan perangkat pembelajaran yang terdiri dari RPP soal Ulangan harian, dan LKS dan alat-alat pengajaran yang mendukung.

Secara spesifik langkahlangkah yang akan dilakukan dalam 
metode pembelajaran Kooperatif Tipe STAD ini adalah sebagai berikut :

a. Membentuk 5 kelompok siswa yang beranggota 7 orang dan 1 kelompok beranggotakan 4 orang secara heterogen (campuran menurut prestasi, jenis kelamin, suku )

b. guru menyajikan pelajaran

c. guru memberikan tugas kepada kelompok untuk dikerjakan sampai semua anggotanya dalam kelompok itu mengerti, tetapi dalam hal ini hasil pekerjaannya dikumpulkan secara individu.

d. guru memberi kuis/pertanyan kepada seluruh siswa.

e. Pada saat siswa mengerjakan kuis, guru berkeliling melihat kerja kelompok, sesekali waktu memberikan penghargaan yang lebih diutamakan pada kerja kelompok dari pada perorangan.

f. Memberikan kesempatan kepada kelompok untuk melakukan presentasi

g. Melakukan evaluasi sebagai penutup.

Kelebihan dengan cara ini seluruh siswa menjadi siap dan dapat melatih kerjasama siswa dengan baik.

Proses pembahasan materi ini diawali dengan penjelasan teknis dan materi pembelajaran oleh guru sekitar 30 menit yang menjelaskan tentang hal-hal sebagai berikut :

a. Menyampaikan tujuan pembelajaran yang ada dalam Standar Kompetensi dan
Kompetensi Dasar beserta Indikator yang akan dicapai.

b. Memotivasi siswa untuk memulai pembelajaran

c. Menjelaskan tentang bagaimana upaya untuk memahami materi ajar suhu dan pengukuran

d. Selama 25 menit kelompok diberi waktu untuk melakukan Diskusi dan menyusun laporan tertulis dari hasil diskusi.

e. Penampilan kelompok sesuai dengan teknik yang sudah diberikan, masing-masing kelompok diberi waktu 10 menit.

f. Selama 25 menit, guru memandu kelompok untuk membahas tentang bagaimana upaya memahami materi ajar suhu dan pengukuran

Total waktu yang dipakai dalam Siklus Pertama ini adalah 100 menit .Pada akhir proses belajar mengajar Siswa diberi tes Ulangan harian dengan tujuan untuk mengetahui tingkat keberhasilan Siswa dalam proses belajar mengajar yang telah dilakukan.

Selama proses pembelajaran berlangsung guru dan Kolabolator/Observer melakukan penilaian proses dari pengamatan terhadap kinerja kelompok, maupun pada saat pleno dengan menggunakan lembar observasi yang telah disediakan. Aspek Partisipasi/Keaktifan Siswa yang diamati selama proses pembelajaran berlangsung meliputi : 
Erlina Purba : Meningkatkan Hasil Belajar ....

Tabel Hasil Observasi Siklus Pertama

Partisipasi Siswa dalam Proses Pembelajaran

\begin{tabular}{|l|l|c|c|}
\hline NO. & \multicolumn{1}{|c|}{ Aspek yang Diamati } & $\begin{array}{c}\text { Jumlah } \\
\text { Siswa }\end{array}$ & Persen \\
\hline 1 & $\begin{array}{l}\text { Mendengarkan Penjelasan guru } \\
\text { dengan tekun }\end{array}$ & 32 & 82,05 \\
\hline 2 & $\begin{array}{l}\text { Ada usaha dan motivasi untuk } \\
\text { mempelajari bahan pelajaran atau } \\
\text { stimulus yang diberikan oleh guru }\end{array}$ & 23 & 58,97 \\
\hline 3 & $\begin{array}{l}\text { Dapat menjawab pertanyaan yang } \\
\text { diberikan oleh guru dengan benar pada } \\
\text { akhir pelajaran }\end{array}$ & 23 & 58,97 \\
\hline 4 & $\begin{array}{l}\text { Dapat bekerja sama dan } \\
\text { berhubungan dengan siswa lain }\end{array}$ & 23 & 58,97 \\
\hline 5 & $\begin{array}{l}\text { Mengajukan pendapat, bertanya atau } \\
\text { berkomentar kepada guru dan siswa }\end{array}$ & 17 & 43,58 \\
\hline 6 & $\begin{array}{l}\text { Aktif berdiskusi untuk memecahkan } \\
\text { masalah }\end{array}$ & 17 & 43,58 \\
\hline 7 & $\begin{array}{l}\text { Mengerjakan tugas yang diberikan } \\
\text { oleh guru dan Mampu membuat } \\
\text { simpulan sendiri tentang pembelajaran } \\
\text { yang diterimanya }\end{array}$ & 26 & 66,66 \\
\hline 8. & Hasil Belajar Tuntas & 30 & 76,92 \\
\hline & \multicolumn{1}{|c|}{ Rata-rata } & 61,21 \\
\hline
\end{tabular}

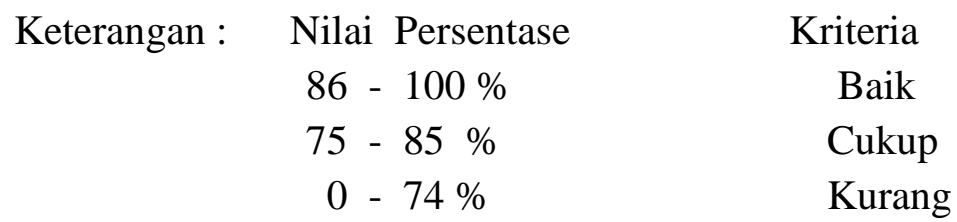

Sama dengan pelaksanaan pada Siklus Pertama, maka pada Siklus Kedua ini ada dua aspek yang ingin diukur yaitu Penilaian Proses Pembelajaran dan Hasil Pembelajaran. Indikator yang digunakan juga sama dengan yang diterapkan pada Siklus Pertama yaitu ada 8 aspek yang diharapkan pada Siklus ke dua ini sudah mencapai $86 \%$ ke atas bobot atau nilainya. Tinggi rendahnya tingkat partisipasi siswa dalam proses pembelajaran dapat diketahui dari nilai hasil pengamatan yang dilakukan.

Materi Pembelajaran yang menjadi bahan penelitian ini adalah Kompetensi Dasar Melakukan pengukuran dasar secara teliti dengan menggunakan alat ukur yang sesuai dan sering digunakan dalam kehidupan sehari-hari. Untuk mencapai effektivitas pembelajaran lebih meningkat dari kondisi Siklus 
Pertama maka telah dibuat Rencana Pelaksanaan Pembelajaran yang disesuaikan dengan metode pembelajaran yang akan diterapkan yaitu Kooperatif Tipe STAD. Pada tahap ini peneliti juga mempersiapkan perangkat pembelajaran yang terdiri dari RPP 2, soal tes Ulangan Harian 2 dan alat-alat pengajaran yang mendukung.

Secara spesifik langkahlangkah yang akan dilakukan dalam model pembelajaran Kooperatif Tipe STAD ini juga dilakukan seperti yang diuraikan pada Siklus Pertama yaitu Membentuk 5 kelompok siswa yang beranggota 7 orang dan 1 kelompok beranggotakan 4 orang secara heterogen (campuran menurut prestasi, jenis kelamin, suku). a. Guru menyajikan pelajaran sesuai dengan Kompetensi Dasar yang diteliti.

b. guru memberikan tugas kepada kelompok untuk dikerjakan sampai semua anggotanya dalam kelompok itu mengerti, tetapi dalam hal ini hasil pekerjaannya dikumpulkan secara individu.

c. guru memberi kuis/pertanyan kepada seluruh siswa.

d. Pada saat siswa mengerjakan kuis, guru berkeliling melihat kerja kelompok, sesekali waktu memberikan penghargaan yang lebih diutamakan pada kerja kelompok dari pada perorangan.

e. Memberikan kesempatan kepada kelompok untuk melakukan presentasi

f. Melakukan evaluasi sebagai penutup.

Tabel Hasil Observasi Siklus Kedua Partisipasi Siswa dalam Proses Pembelajaran

\begin{tabular}{|l|l|c|c|}
\hline NO. & \multicolumn{1}{|c|}{ Aspek yang Diamati } & $\begin{array}{c}\text { Jumlah } \\
\text { Siswa }\end{array}$ & Persen \\
\hline 1 & $\begin{array}{l}\text { Mendengarkan Penjelasan guru } \\
\text { dengan tekun }\end{array}$ & 36 & 94,87 \\
\hline 2 & $\begin{array}{l}\text { Ada usaha dan motivasi untuk } \\
\text { mempelajari bahan pelajaran atau } \\
\text { stimulus yang diberikan oleh guru }\end{array}$ & 36 & 94,87 \\
\hline 3 & $\begin{array}{l}\text { Dapat menjawab pertanyaan yang } \\
\text { diberikan oleh guru dengan benar pada } \\
\text { akhir pelajaran }\end{array}$ & 34 & 92,30 \\
\hline 4 & $\begin{array}{l}\text { Dapat bekerja sama dan } \\
\text { berhubungan dengan siswa lain }\end{array}$ & 34 & 97,43 \\
\hline 5 & $\begin{array}{l}\text { Mengajukan pendapat, bertanya atau } \\
\text { berkomentar kepada guru dan siswa }\end{array}$ & 34 & 97,43 \\
\hline 6 & $\begin{array}{l}\text { Aktif berdiskusi untuk memecahkan } \\
\text { masalah }\end{array}$ & 35 & 97,43 \\
\hline 7 & $\begin{array}{l}\text { Mengerjakan tugas yang diberikan } \\
\text { oleh guru dan Mampu membuat }\end{array}$ & 35 & 97,43 \\
\hline
\end{tabular}


Erlina Purba : Meningkatkan Hasil Belajar ....

\begin{tabular}{|c|c|c|c|}
\hline & $\begin{array}{l}\text { simpulan sendiri tentang pembelajaran } \\
\text { yang diterimanya }\end{array}$ & & \\
\hline 8. & Hasil Belajar Tuntas & 34 & 94,87 \\
\hline & Rata-rata & & 95,82 \\
\hline
\end{tabular}

Keterangan: Nilai Persentase

$86-100 \%$

$75-85 \%$

$0-74 \%$

\section{Pembahasan}

Sebagaimana diuraikan pada latar belakang penelitian ini bahwa aktivitas siswa atau partisipasi siswa dalam proses pembelajaran sangat rendah sehingga pembelajaran dirasakan kurang bermakna dan kurang membangun potensi atau pengetahuan yang telah dimilikinya. Akibatnya, hasil belajar siswa menjadi rendah.

Rendahnya tingkat partisipasi siswa dalam membahas materi pelajaran terlihat dari kondisi-kondisi berikut ini :

a. Keterlibatan siswa dalam membahas materi pelajaran rendah, karena siswa kurang diberi tanggung jawab.

b. Kemampuan siswa untuk menyampaikan pendapat rendah, karena siswa sering diberlakukan sebagai obyek belajar.

c. Kemampuan siswa untuk bertanya rendah, karena siswa tidak memahami konsep yang sedang dibahas sehingga ia tidak mengetahui apa yang harus ditanyakan akibatnya ia tidak mampu mengerjakan tugas yang diberikan oleh guru dan tidak mampu membuat simpulan
Kriteria
Baik
Cukup
Kurang

sendiri tentang pembelajaran yang diterimanya.

Kemampuan siswa menjawab pertanyaan hanya terdapat pada siswa-siswa yang termasuk dalam kategori pandai. Kurangnya kemampuan berbagi pengalaman antara siswa pandai dengan yang kurang pandai menjadi pemicu semakin membuat siswa-siswa yang kurang pandai tidak memiliki keterampilan dan kemampuan serta keberanian untuk menyampaikan pertanyaan dan pendapatnya dalam diskusi kelompok maupun dalam kegiatan belajar.

\section{SIMPULAN}

a. Dari hasil siklus I menunjukkan bahwa terjadi peningkatan jika dibandingkan dengan sebelum pembelajaran dengan model pembelajaran kooperatif tipe STAD dari 36 siswa yang mengalami ketuntasan belajar sebanyak 20 siswa ( 55\%) dan siswa yang tidak mengalami ketuntasan belajar sebanyak 16 siswa ( 45\%) . Pada siklus II siswa yang mengalami ketuntasan belaajar sebanyak 28 siswa (77\%) dan siswa yang 
tidak mengalami ketuntasan belajar sebanyak 8 siswa ( $23 \%$ ) . Dari perolehan siklus II hasil Belajar siswa sudah mencapai ketuntasan klasikal $75 \%$.

b. Dari data hasil Belajar model kooperatif tipe STAD dapat meningkatkan hasil belajar siswa kelas VI SD Negeri 163084 Kota Tebing Tinggi Tahun Pelajaran 2016/2017.

\section{DAFTAR RUJUKAN}

Abdullah, A,E. 1989. Pokok-pokok Layanan Bimbingan Belajar. Ujung Pandang: Fakultas Ilmu Pendidikan IKIP Ujung Pandang.

Abdurrahman, H. 1990. Pengelolaan pengajaran. Bandung: Tarsito.

Agus Kristiyanto. 2013. Penelitian Tindakan Kelas (PTK); Dalam Pendidikan Jasmani \& Kepelatihan Olahraga. Surakarta: UNS press.

Agus Margono. 2010. Permainan Bola Basket. Surakarta: UNS perss.

Ahmadi \& Amri. 2011. Paikem Gembrot. Jakarta: Prestasi Pustaka.

Arikunto, S. 1993. Prosedur Penelitian dan Penilaian Hasil Belajar. Jakarta : Bina Aksara.

Aunurrahman. 2011. Belajar dan Pembelajaran. Bandung: Alfabeta.

Aqib, Zainal. 2009. PENELITIAN TINDAKAN KELAS. Bandung: Rama Widya.
Ahmadi, Abu. 1998. Didaktik Metodik. Cet.II. Semarang: CV. Toha Putra.

Ali, M. 1993. Guru dan Proses Belajar Mengajar. Bandung: Sinar Baru Algesindo.

Boediono. 1998. Pembinaan Profesi guru dan Psikologi Pembinaan Personalia. Jakarta: Departemen Pendidikan dan Kebudayaan.

Bahri, D.S. 1994. Prestasi Belajar dan Kompetensi guru. Surabaya: Usaha nasional.

Edward, J.D. 1995. Statistik Matematika Modern. Jakarta: PT. Gramedia Pustaka Utama.

Gie. 1995. Cara Belajar yang Efisien. Yogyakarta: Liberti.

Hardjana. 1994. Kiat Sukses di Perguruan Tinggi. Yogyakarta: Kanisius.

Hudoyo, H. 1984. Pengembangan Kurikulum. Surabaya: Usaha Nasional.

Loekmono. $1994 . \quad$ Belajar Bagaimana Belajar. Jakarta: BPK Gunung Mulia.

Mappa, S, 1970. Psikologi Pendidikan. Ujung Pandang: Fakultas Ilmu pendidikan IKIP Ujung pandang.

Mardanu. 1997. Peranan Orang Tua dalam Upaya meningkatkan Mutu Pendidikan anak. Jakarta: Cakrawala Pendidikan.

Mathis dan Jackson. 2002. Manajemen Sumber Daya Manusia. Jakarta : Salemba Empat. 